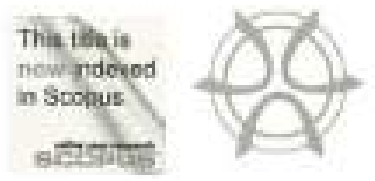

PLANNING MALAYSIA

Geosparial Analysis in Urban Planning

Volume II (2013), Page 137 - 162

\title{
SEISMIC MICROZONATION FOR BANDA ACEH CITY PLANNING
}

\author{
Foziah Johar', M. Rafee Majid ${ }^{2}$, Abdul Razak Jaffar ${ }^{3} \&$ Adi Safyan \\ Yahya $^{4}$ \\ ${ }^{2,243}$ Centre for Innowative Planning and Development (CIPD) \\ Facuity of Built Environment \\ UNIVERSITI TEKNOLOGI MALAYSLA \\ ${ }^{4} K A R Y A$ CIPTA ESTETIKA, BANDA ACEH, INDONESIA
}

\section{Abstract}

Of all natural disasters of the twentieth century, earthquakes caused the largest amount of losses. Although the number of earthquakes remains fairly unchanged, the loss of properties and human lives in recent periods has increased manifolds due to increasing concentration of human population and urbanisation in earthquake-prone areas. Recent improvement in documentations and computational facilities, however, allows for the preparation of seismic microzonation maps of such areas for urban planning and earthquake mitigation purposes. This paper discusses the development of seismic microzonation maps for Banda Aceh which lies close to the Sumatra Subduction Zone and the Sumatran Transform Faults, making the city extremely vulnerable to earthquake hazards. The development of the maps employs Geographic Information Systems (GIS) techniques that make use of several layers of parameters influencing earthquake hazards such as seismological data, faults, tsunami, etc. and site characteristic data such as soil type, groundwater distribution and depth, geological and geophysical data. The seismic microzonation maps incorporate various seismic hazard maps including ground shaking hazard map, liquefaction susceptibility hazard map, landslide potential hazard map, surfice faulting hazard map and tsunami hazard map. The final composite map identifies zones with various degrees of hazards which will enable planners to avert hazardous locations during site selection processes, thus reducing losses.

Keywords: Earthquakc, Seismic, Hazard, Mitigation, Microzonation, GIS.

\footnotetext{
I Asscciate Professor at Department of Liban and Repicnal Planning. Faculty of Buat Envincement, Univessiti Teknologi Malaysia. Email: b-foriahieutm.my (Correspondias Author)
} 


\section{INTRODUCTION}

Earthquake is one of the most devastating natural disasters which can cause severe impact on human life, loss of valuable goods and massive damage to structures such as buildings, transportation systems and communication systems. It can even lead to total devastation of eities. There are many earthquakes that are well known not just for their magnitude but also for the damage and casualties they caused. A compendium report on the significant earthquakes worldwide, from the oldest to the most recent ones, lists the tremendous loss of lives and property dumage caused by earthquakes (Chen and Scawthom 2003). The damage caused is not only dependent on the magnitude of the earthquakes and the distance from the epicentre, but also on the level of socio-economic activities in the area. Though the number of incidences of large earthquakes has remained fairly stable, the recent magnitude of losses of properties and human lives has increased tremendously due to the intensification of urbanisation and economic activities, especially in larger urban areas situated in susceptible regions. However, intense urbanisation alone is not a single most important factor since the level of earthquake preparedness can, on the other hand, lessen the impact. Developed countries that have in place more sophisticated warning-systems and stricter building codes as well as restrictive land use zoning ane less susceptible and more resilient to earthquake damage compared to underdeveloped countries, given the same magnitude of earthquakes (Westen 2002: Walling and Mohanty 2009). Thus, it is therefore erucial for these underdeveloped countries to determine what kind of predisaster initiatives can belp mitigate disaster risk, especially in urban areas.

Although the occurrence of earthquakes is inevitable, the social and economic setbacks following the occurrence can te reduced through a comprehensive assessment of the seismic hazards. Most countries that are suseeptible to earthquakes have developed seismic zones which lave been regarded as a basic tool for earthquake damage mitigation (Coburn and Spence 2002; Roca et al. 2006; Ansal et al. 2009); but these are deemed inadequate for planning purposes as more detailed assessments are needed. A more detailed seismic zonation or seismic microzonation maps are able to provide a more detailed assessment of potential earthquake effects which include ground shaking, liquefaction, landslide, surface faulting and tsunami susceptibilities which are more useful as guidance to urban planning and development. At the urban level, the identification of relative hazand variations due to different earthquake characteristics can be used to introduce earthquake effects as a relevant factor in land use planning and management. 
Looking back at the mega earthquake that struck Banda Aceh in northem Sumatra, Indonesia on December $26^{\text {th }} 2004$, we cannot help but think that the vulnerability of Banda Aceh to earthquake hazards underlines the value in considering risk mitigation measures for future development. Thus it is the aim of this study to develop a comprehensive seismic microzonation maps of Banda Aceh using Geographic Information Systems (GIS) coupled with the Analytical Hierarchy Process (AHP). The final composite map will provide guidance to urban planners in deciding on the potential location of future development based on hazard risks.

\section{EARTHQUAKE HAZARD AND URBAN PLANNING}

The damage incurred in an earthquake depends not only on the magnitude of the earthquake but also, to a large extent, on the medium through which the seismic waves propagate and the socio-economic development of the affected settlement (Panza et al. 2001). Hough and Bilham (2005) gave at simple relation discerning between the earthquake magnitude since 1900 and the number of deaths per earthquake but the consequences of large earthquakes depend on the proximity to urban areas, vulnerability of the dwelling inhabitants, time of the day and on the energy released (Figure 1).

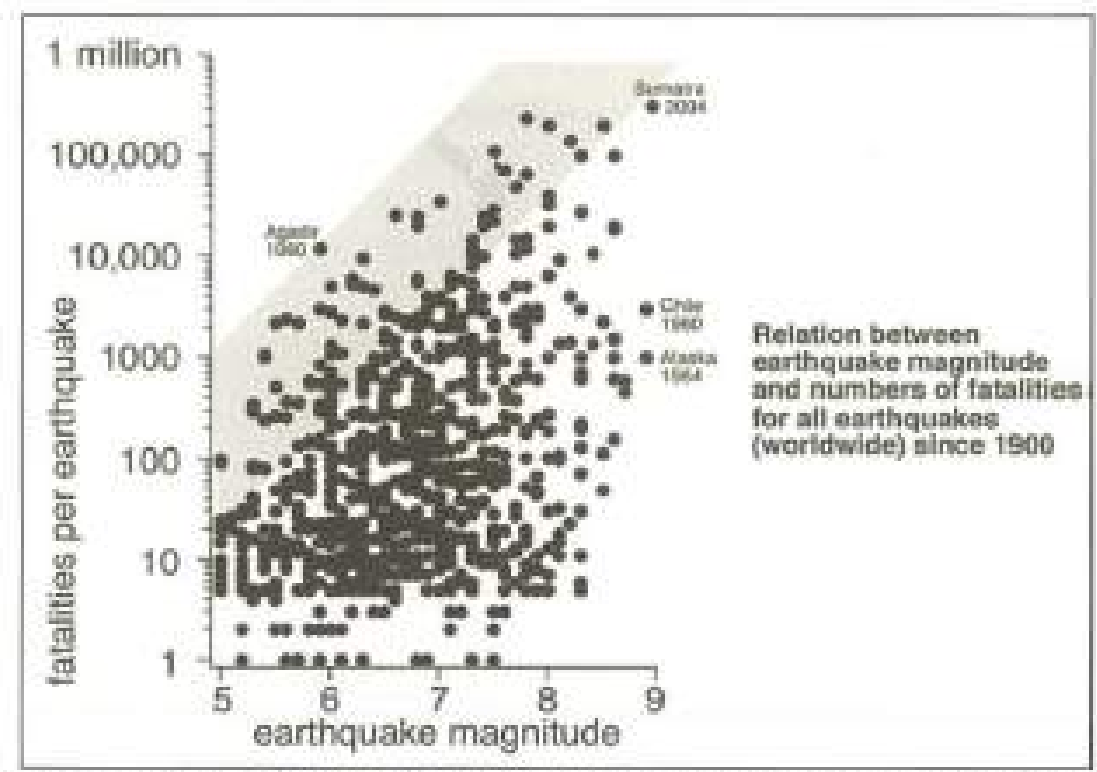

Figure 1: A Simple Relation Discerning between Earthquake Magnituxle and the Number of Futalities (grey shading) 
When disasters strike cities, the effects can be worse than in other environments, and it is the poor and marginalized communities in the developing countries that face the greatest risks (e.g. Blaikie et al. 1994; IDNDR 1990). With growing urbanisation and increasing occurrences of small and large-scale disasters in urban areas, years of development effort and labour are continually being destroyed and eroded (Sanderson 2000). Maskrey (UNDPBCPR 2004) puts it best when he stated: "The trend is for the risk to become uban". Increasing natural disasters in urban areas are contimuously testing our public policies and disaster response measures beyond their capacities (Mitchell 1999).

In response to this development, it is essential to determine effective pre-disaster initiatives that can help to mitigate disaster risk. However, those involved in risk reduction and planning issues are not fully aware of the interconnection between planning and the occurrence of natural disasters (Wamsler 2004). This results in few initiatives being developed, which would integrate both fields. According to Pelling (2003), urbanisation affects disasters just as profoundly as disasters can affect urbanisation. In addition, rapid urbanisation is a factor that calls for construction of mega structures, and the main reason for human loss and property damage is lack of due considerations on the importance of adequate preparation for possible hazards. In many developed countries, however, improvements in methods for risk reduction, together with good planning, have greatly reduced the vulnerability and risk of the population (Velasquez et al. 1999). The city of Tokyo, for example, promotes 'disaster-proof urban planning' and prescribes regulations on the implementation of 'area vulnerability assessments' (Velasquez et at. 1999). An example from the developing world is Cuba, where national land-use planning and management are integrated into risk reduction considerations (UN-ISDR 2002).

Planning process rarely includes measures needed in reducing hazards, and consequently, natural disasters would result in severe economic and human suffering, Right from inception, planners and decision makers should evaluate natural hazards as they do in preparing investment projects and promote ways of avoiding or mitigating damage caused by natural catastrophic events. Adequate planning can minimize damage from natural catastrophic events. Integrating natural hazands management into development planning can pick up the planning process in the area and thus reduce the impact of natural hazards (OAS/DRDE 1991).

Site selection is the most important stage in planning a settiement or constructing a building in an earthquake-prone area. Evaluation of the degree 
of earthquake hazard should always be part and parcel of the general site evaluation and of the design requirement of any structure to be erected on such sites. A perfect site is almost none existence, thus the likely risk of earthquake hazards on a site and the costs of designing to minimize adverse effects from it should be considered. Unsafe sites should be avoided, because the mitigation costs are likely to be exorbitunt.

Mapping of earthquake hazards at the regional or urban level makes it feasible in the selection of relatively less affected sites for the distribution of suitable land uses. Patterns of urban development can be oriented toward these relatively less affected regions to reduce likely earthquake damages. For this, seismic microzonation is a fundamental tool for structural designers and builders as it enables them to expect predicaments related to amplification of ground shaking, liquefaction and landslide susceptibilities (Ansal et al. 2009). The design loading and other inputs for the structural design of buildings should be provided as part of the information derived from the site assessment. Mostly this process is very much facilitated through the use of zoning map and other additional procedures addressed by pre-determined code of practice. In a situation where such code is not available, a more meticulous analysis is needed (Coburn and Spence 2002).

Seismic waves generated at the earthquake source propagate through different geological formations until they reach the surface at a specific site. The travel paths of these seismic waves in the uppermost geological layers strongly uffect their characteristics, producing different effects on the earthquake motion at the ground surface (Figure 2). In general, thicker layer of soft, unconsolidated deposits tend to amplify selectively different wave frequencies. On the other hand, the local topography can also modify the characteristics of the incoming waves, leading to the so called topographic effects. Soil and topographic effocts are considered under the general denomination of local site effects. Beyond these effects and under certain circumstances, induced effects may occur for lange amplitude incoming waves, among which are slope instabilities (landslides) in mountainous area and liquefaction in recently deposited sands and silts area (Figure 2). 

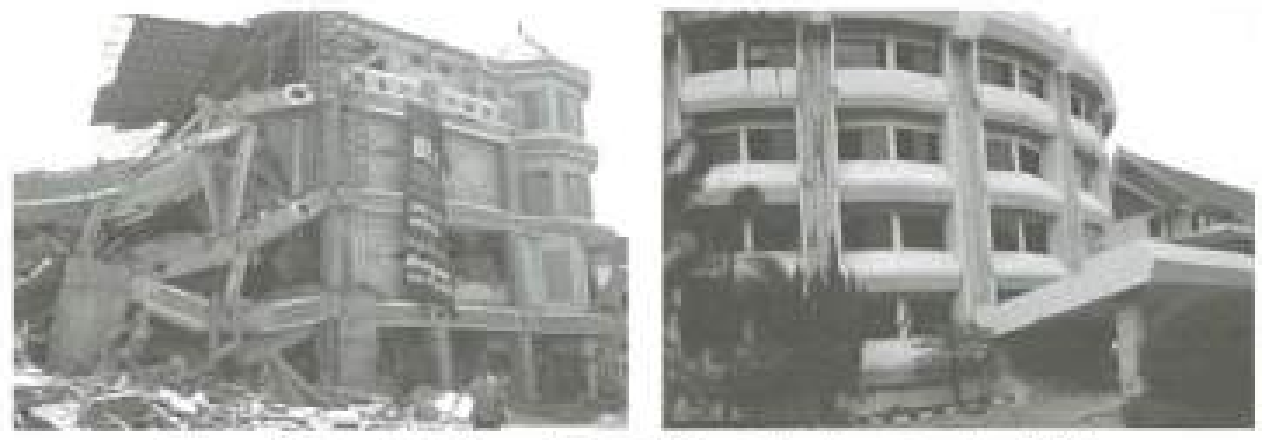

Figure 2: Ground shaking effects in Banda Aceh earthquake, 2004
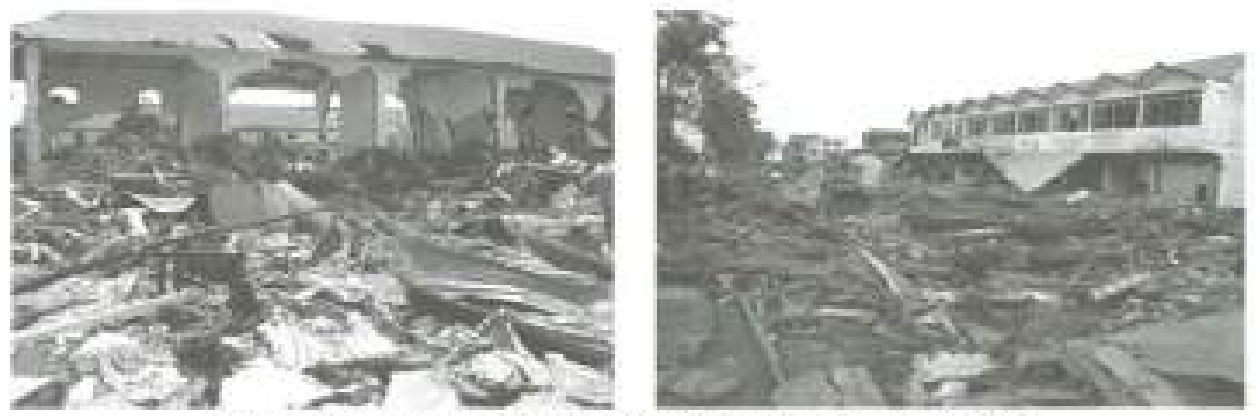

Figure 3: Tsunami effects in Banda Aceh earthquake, 2004

Simer: How 2005

Within a more generalized scope, active faulting should also be considered, In addition, permament differential displacements and near fault effects are other important issues to be recognized. Earthquake induced tsunami is also considered in the coastat area, especially the site near to the fault rupture in sea bed (Figure 3). In many past and recent earthquakes, it has been observed that the local site conditions, i.e. soil and topographic effects, as well as induced effects, have a great influence on the damage distribution. It is therefore, very important to take into account and predict these possible local site effects when assessing the earthquake hazard at regional and local scale.

\section{Seismic Microzonation}

Seismic microzonation can be defined as the subdivision of a region that has relatively similar exposure to various earthquake-related activities or the identification of individual areas with varying potentials for earthquake effects. The underlying concept arises from the fact that the effects of surface geology on seismic motion could be considerably large. Several studies on devastating 
earthquakes have demonstrated a large concentration of damage in specific areas due to site-dependent factors related to surface geologic conditions and local soils altering seismic motions (Nath et al. 2008).

Various approaches are currently being applied for microzonation studies. Experimental techniques, together with theoretical approaches involving ground motion modelling under difterent hypotheses have been used to classify urban areas into zones with different earthquake response characteristics. Microzonation is normally classified into three levels (TC4ISSMGE 1999):

a) First grade (Level 1) map prepared with a scale of 1:1,000,000 $1: 50,000$ showing the seismic hazards assessed based on the historical earthquakes and existing information of geological and geomorphological maps.

b) Second grade (Level II) map prepured with a scale of $1: 100,000$ 1:10,000 showing the seismic hazards assessed based on the microtremor and simplified geotechnical studies.

c) Third grade (Level III) map prepared with a scale of 1:25,000-1:5,000 showing seismic hazards assessed based on the complete geotechnical investigations and ground response analysis.

The three levels are calibrated with respect to their specific ase and relevant objectives. For vast area land planning the first level is sufficient, while level 2 or level 3 are usually needed for securate urban and emergency planning and for structural design (Dolce 2002). The key issue affecting the applicability and the feasibility of any microzonation study is the usability and reliability of the parameters selected for mictozonation. The locations of concern, for which the preparation of seismic microzonation is most needed, is the urban or upcoming urban area that falls under the high seismic hazard zone; and locations with moderate (or low) hazard but with potential amplification due the local geological conditions. The pattem of damage due to an earthquake depends largely on the local site condition and the social infrastructures of the region, the most important condition being the intensity of ground shaking at the time of the earthquakes. Contrasting seismic response has been observed even within a short distance over small changes in the geology of the site. Moreover, designing and constructing structures on all sites to withstand conceivable future earthquake is economically not viable. As such, in terms of land-use management or city/urban and regional planning, seismic microzonation map can be regarded as an appropriate tool to minimize the impact of earthquakes. 


\section{THE STUDY AREA}

The study area covers about $1160 \mathrm{~km}^{2}$.It includes the city of Banda Aceh (Banda Acch Municipality) which is an area of $60 \mathrm{~km}^{2}$ and $1100 \mathrm{~km}^{2}$ or balf of the area of Great Aceh Regency (Figure 4). Banda Aceh is the provincial capital and the largest city in the province of Aceh, located on the northern most tip of Sumatra Island, Indonesia. It is the most populous eity in the region with the highest concentration of human activities and manmade structures, particularly along the eastern coastlines of the city. It serves as the principal administrative, commercial, educational and cultural eentre of Aceh Province. Banda Aceh is located on latitude between $95^{\circ} 16^{\prime} 15^{\prime \prime}-95^{\circ} 22^{\prime} 15^{\prime \prime}$ East and longitude between $05^{\circ} 16^{\prime} 15^{\prime \prime}-05^{\circ} 36^{\prime} 16^{\circ}$ North.

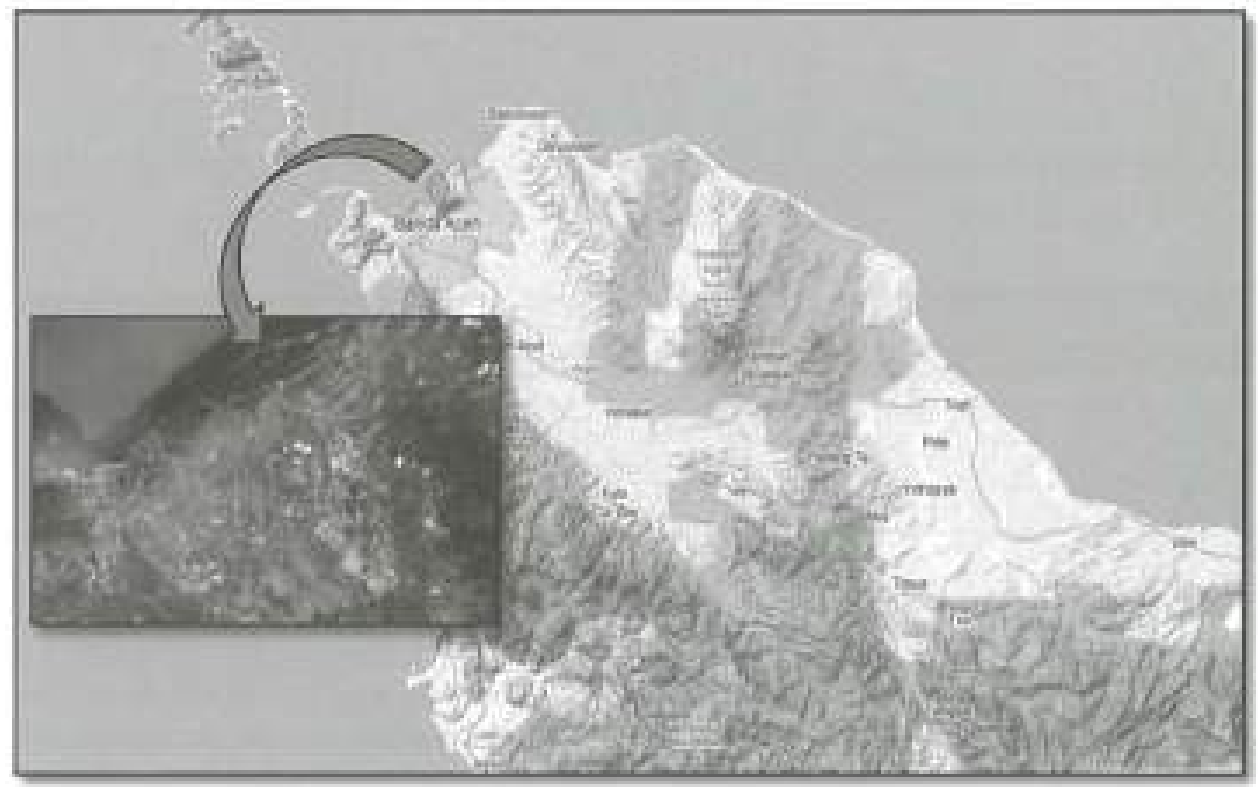

Figure 4: Locstion of the study anea

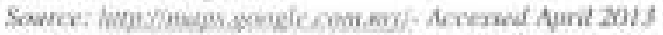

\section{Topographical and Geological Settings}

Banda Aceh is located on the detaic plain of Aceh River (Krueng Acch). The city stands astride the broad valley of Aceh River which flows between the low Tertiary and Quaternary volcanic hills to the east and Cretaceous limestone hills to the west (Figure 5). The valley itself is filled with relatively recent alluvial and marine sediments to depths in excess of 179 metres (Culshaw et al. 1979). These were deposited in a graven structure formed between the main Sumatran 
Fault System. The valley is relatively low lying ground with little relief in the lower part of the valley, and relatively higher relief in the upper part of the valley, much of the land is at less than 5 metres above sea level. The deltaic plain emerged mainly as a wide tidal area spreading over $1-2$ kilometres to the coast with elevation $0-3$ metres above the sea level. However, terraced areas on the eastern and western margins rise to over 30 metres. The deltaic lowland and beach ridges are occupied by houses while the Banda Aceh urban area is located on the deltaic plain in the central part of the coastal plain (Umitsu et al. 2006).

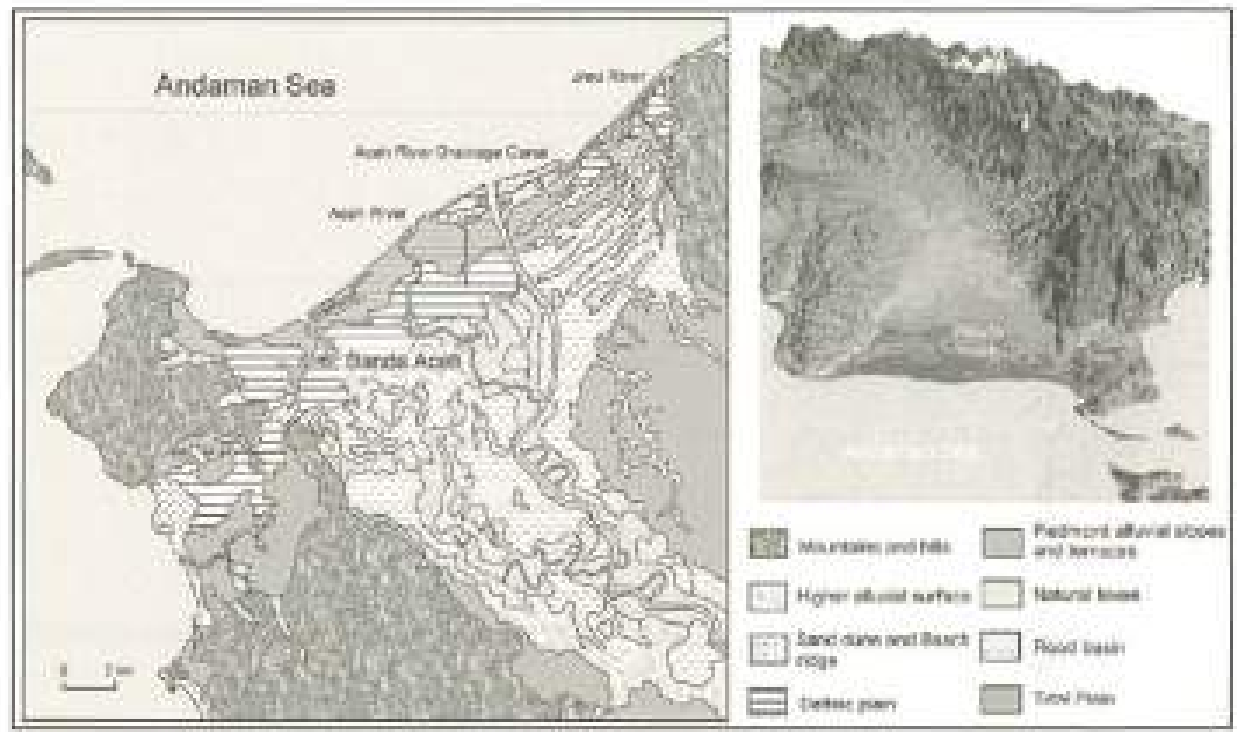

Figure 5: Topography of the study area

The oldest rocks in the Banda Aceh area are limestone, slates and phyllites outerops on the west side of the Aceh River valley. These are of Cretaceous uge and form genenally steep mountains at the northern end of the Barisan mountains range that runs the length of Sumatra Island. The limestone is fairly massive but moderately weathered. The east side of the valley is flanked by extensive deposits of andesitic tufts and subsidiary flows, some probably water lain (Culshaw et al. 1979). These deposits and their parent voleano, Seulawah Agam, lie on the line of the eastern Sumatran Fault, a splay off the main fault system.

The valley can be divided into three areas on the basis of the location and distribution of the deposits: the lower part (the coastal area), the middle part (along Aceh River) and the upper part (higher alluvial surface and terraces). The 
most northerly area (coastal area) consists of five to six kilometres wide coastal strip, with a series of ancient sindbars, running sub-parallel to the coast. These consist mainly of brown to grey, moderately weathered, fine to medium grained, sometimes silty sands. Weathering extends to a depth of about 2 metres. The lithological composition of these sandbars is very similar to that of the modern beach sands on the coast and to sand deposits in the channel of the Krueng Aceh.

\section{Seismicity of the Region}

Indonesia has been well known as one of the most seismically active countries in the world. This is due to its location as it is surrounded by four major active tectonic plates of the earth: Euro-Asian (Eurasian), Indian-Australian, Pacific and Philippine plates. The location of Banda Aceh near to one of the most scismically active plate, the subduction zone of India-Australian Plate (Sumatran Subduction Zone) (Zachariasen et al. 1999), and very close to the segments of Sumatran Transtorm Fault (Aceh and Seulimeum segment), makes it vulnerable to earthquake hazards. The study of probabilistic seismic and tsunami hazard analysis of Banda Aceh by Sengara et al. (2008), based on instrumental and historical data and potential magnitude estimated from geometry and slip rate of the plates or faults, assigned the Moment Magnitude (Mw) of earthquake in subduction zone that could trigger tsunami at Mw 9.3 in 520 years return period, Mw 8.5 in 250 years return period. Mw 8.0 in 120 years return period and 7,5 in 50 years retum period.

The Sumatra subduction zone is a very active feature that has nuptured 237 times with magnitude greater than or equal to Mw 5 within the past 36 years (Petersen et al, 2004). Four past major earthquakes that were reconded were two in the $1800 \mathrm{~s}$ 1.e. Mw of 8.75 in 1833 and Mw of 8.4 in 1861: and another two in recent years i.e. Mw of 9.3 Aceh earthquake in Dec 2004 and Mw of 8.7 Nias earthquake in March 2005. The locations of these four earthquakes including the rupture zones are shown in Figure 6. The low-lying city of Bandia Aceh was one of the worst affected regions and experienced massive casalalties and destruction of properties, as it was close (ca, $150 \mathrm{~km}$ ) to the source of the earthquale. The tsunami flow extended inland towards the central and western parts of the Banda Aceh plains for approximately $4 \mathrm{~km}$ and about $3 \mathrm{~km}$ towards the eastern part (Figure 7). The tsunami reached a height of 9 meters on the ground near the port of Banda Aceh and about $6-8$ meters in the eastern part of the plain. The loss of human life recorded was the highest at about two-thirds of the total of 300,000 casualties (Meilianda et al. 2010), 


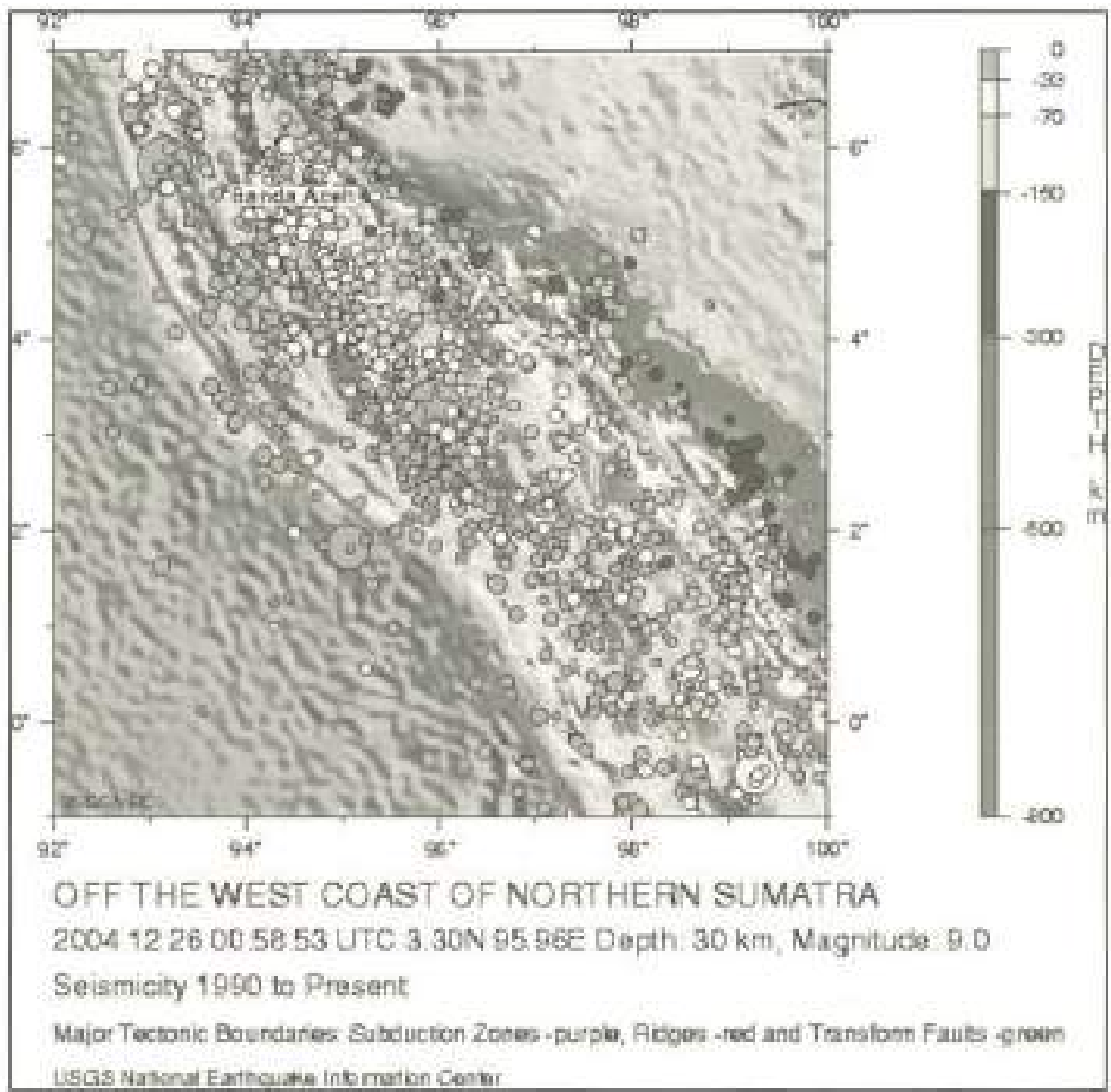

Figure 6: Seismicity of the region affected by Sumatra Subduction Fault (purple) and Sumatran Transform Fault (green)

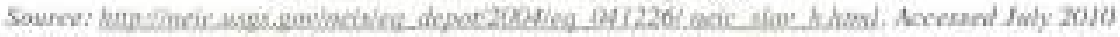




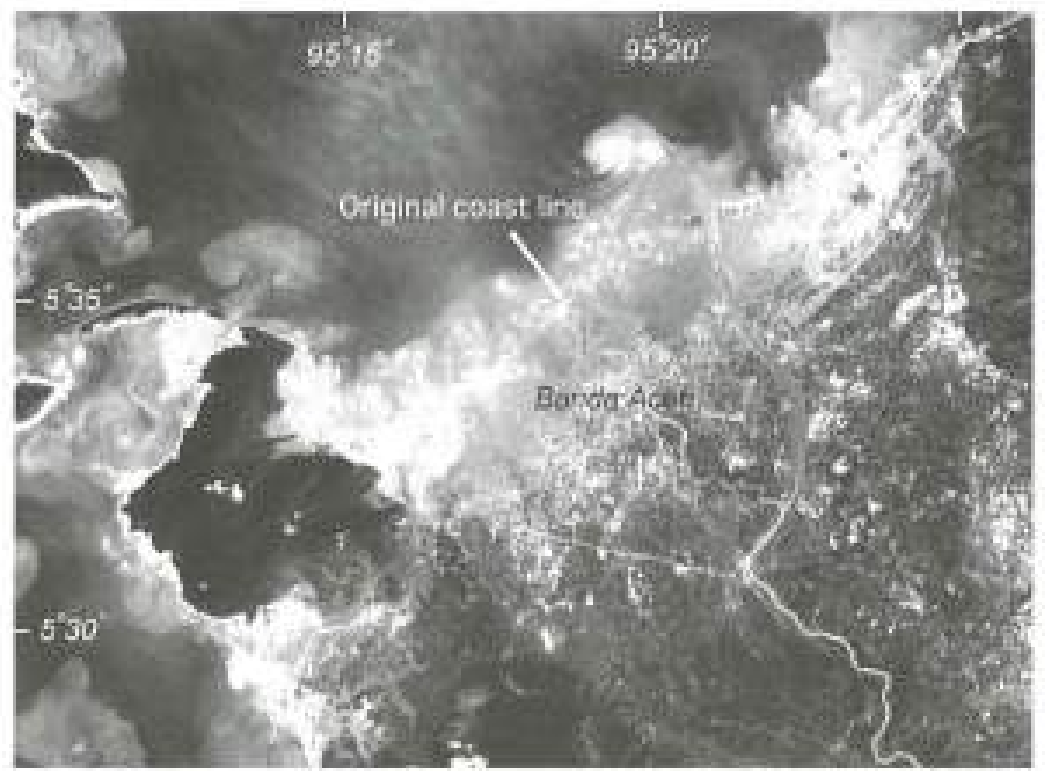

Figure 7: Inundation and tsunami flow of the Banda Ache Plain shown in the SPOT2 image. The image was taken about 4 hours after the eurthquake.

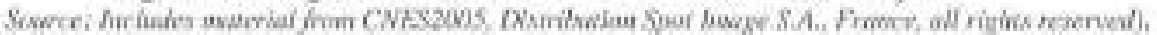
(Eveifn of of 2007)

A probabilistic seismic hazard analysis of the Sumatran subduction zone carried out by Sun and Pan (1995) indicated that the recurrence interval of an earthquake with Mw 8.5 or larger that can generate a tsunami would be about 340 years, which corresponded to a $14 \%$ probability of incidence within 50 years. Because of the large population that inhabits this region, it is prudent to suggest for seismic hazard analyses be conducted to assist in the development planning for the area.

\section{IMPLEMENTATION OF GIS FOR SEISMIC MICROZONATION}

The application of technology required to control the effects of natural hazards comprises three significant elements; prediction, monitoring and safeguarding (Alexander 1995: Turk et al, 2011). In recent years, different technologies have been developed showing possibilities for a wide range of disaster management and hazard mitigation (Yilmaz 2009). This paper focuses on the application of GIS on developing seismic mierozonation for site selection for the purpose of urban planning and management. Microzonation studies is tedious to perform by means of classical methods as it involves voluminous data; the reason why a GIS is needed in order to do it accurately and quickly (Kolat ef al. 2006: Kienzle et al, 2006; Nath 2005; Papadimitriu et al. 2008; Turk 2009). GiS has 
emerged to be a powerful computer-based technique that integrates spatial analysis, database management, and geographical visualization capabilities. This technology has been widely used in producing increasing numbers of seismic zone maps for the prediction of earthquake-induced hazards (Kolat et al. 2006; Sun et al. 2008: Grasso and Maugeri 2009). Guidelines for seismic microzoning developed in countries such as France (AFPS 1995), Japan (TC4ISSMGE 1999) and the Republic of Turkey (DRM/GDDA 2004) show how GIS has been employed to establish GIS database as well as generating seismic microzonation maps. The microzonation maps consist of surface faulting map, ground shaking map, liquefaction susceptibility map, landslide and rock fall hazard map, and earthquake-related flooding hazard map. In Turkey, a seismic microzonation level 3 map, is obtained by investigating a point in a grid format of the study area and imported into GIS software, using geo-statistical interpolation technique (DRM/GDDA 2004), In India, in the absence of guidelines, researchers make assessment based on the theory of seismic microzonation, data availability and relevant objectives of the map.

Another method adopted to produce a seismic microzonation map is by using the technique of weighted overlay. This method assigns weightage to parameters such as seismic data (shear wave velocily, predominant period/frequency, peak ground acceleration/velocity) and site characteristics data (bedrock, soil layer (stratification) and type (classification), groundwater depth and topography). This method is usually used for urban and regional planning (OASDRDE 1991) and broadly used in tndia (Mohanty et al, 2007; Nath et al. 2008; Anbazhagan et al. 2008; Walling and Mohanty 2009). To conclude, many approaches have been employed in producing seismic microzonation maps subject to needs and available guidelines.

\section{DATA AND METHODOLOGY}

For the study on Banda Aceh, the seismic microzonation map which has been developed on a scale of 1:225,000 using ArcGIS ver. 9.3 can be classified as seismic microzonation level 1 (TC4-ISSMGE 1999) which is suitable for vast area planning (Dolce 2002). The seismic microzonation map is based on the analysis of historical seismological records and existing geological, geotechnical and geo-morphological data. The main data for the map was obtained from the Acch Province's Energy and Mineral Resources Department and the Development Planning Agency. They carried out seismological, geological and geotechnical studies for the region and these complemented by seismic data from the U.S. Geological Surveys. The data was categonized into two main themes; seismological data, which include peak ground acceleration 
(PGA), faults, and tsunami inundation maps; and the site characteristics data, which include geology (soil and rock formation), lithology (soil type and classification), hydrology (groundwater quantity and distribution) and topography (contour map). The expected PGA value in the region varies from $0.05 \mathrm{~g}$ to $0.15 \mathrm{~g}$. The highest value is on the alluvial sediments especially on the coastal region in the northern part of the area which is mainly thick clay deposits. The PGA values decrease towards the eastern part which is andesitic deposits, the western part which is limestone deposits, and the southern part which is relatively shallow bedrock. The fault map identifies two segments of the Sumatran transform faults (Aceh and Seulimum segments) located very closed to the eity which implies hard shaking and surface faulting potential along the faults. The tsunami inundation map was made based on the historic tsunami occurrence and have been studied previously (JICA 2005: Borrero 2005; Unitsu et al. 2007; Takahashi et al. 2008: Lavigne et al. 2009)

The seismic microzonation map is developed by first identifying the hazards caused affected by an earthquake in the area which area ground shaking, liquefaction, landslide, surfice faulting and tsunamis. The parameters or criteria and sub criteria for each type and sub criteria for each type of hazard are consequently determined. The parameters and their values can be seen in Figure 8. Ground shaking hazard map, liquefaction hazard map and landslide hazard map are created by using weighted overlays of parameters that influence the level of hazards. This process employed Saaty's (1980) Analytical Hicrarchal Process (AHP). The AHP uses hierarchical structures to represent a problem, and there after develops priorities for the alternatives based on the consensus judgment. The technique utilizes organized priority in terms of weights assigned to each criteria or themes, which could be easily incorporated to the thematic layers on a GIS platform. The weighting activities in multicriteria decision-making are effectively dealt with hicrarchical structuring and pair-wise comparisons wherein the judgment between two particular clements is formulated rather than prioritize an entire list of elements. The process involves construction of a matrix of pair-wise comparisons between the factors of adopted parameters depieting relative importance based on the assigned weightage.

The highest weight is given to the PGA $(0,4)$ as it is directly related to the ground motion and contributes more to the seismic hazard, followed by soil class (0.3), geology (0.2) and groundwater (0.1) (Nath 2004). Rank value is then determined for each sub-criterion. For example in soil-class, unconsolidated soil (soft soil) has worse impact than dense soil or rock. The weight and rank value are used as input in weighted overlay analysis (Malczewski 1999) to generate the ground shaking hazard map. The surface faulting hazard map is created by 
calculating the distance from the faults and reclassifying the distance into different hazand levels while the tsunami hazard map is generated by reclassifying the historic tsunami inundation map.

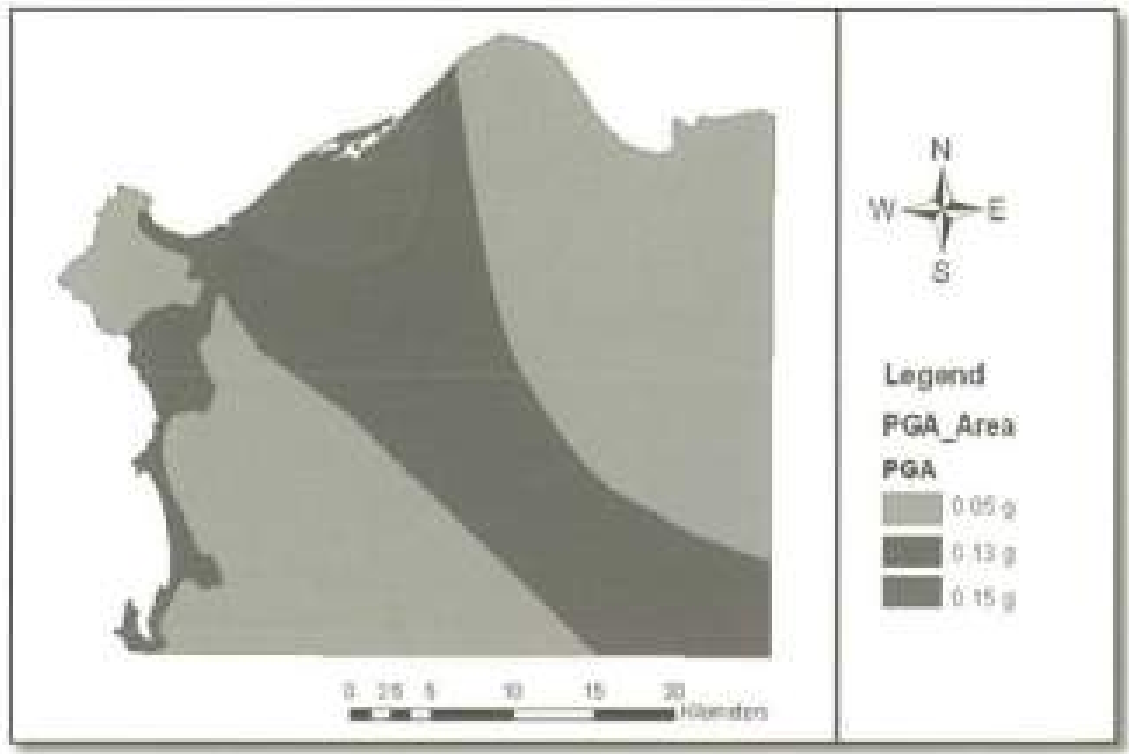

Figure 8: Pcak Ground Accelenation (PGA) Data Layet

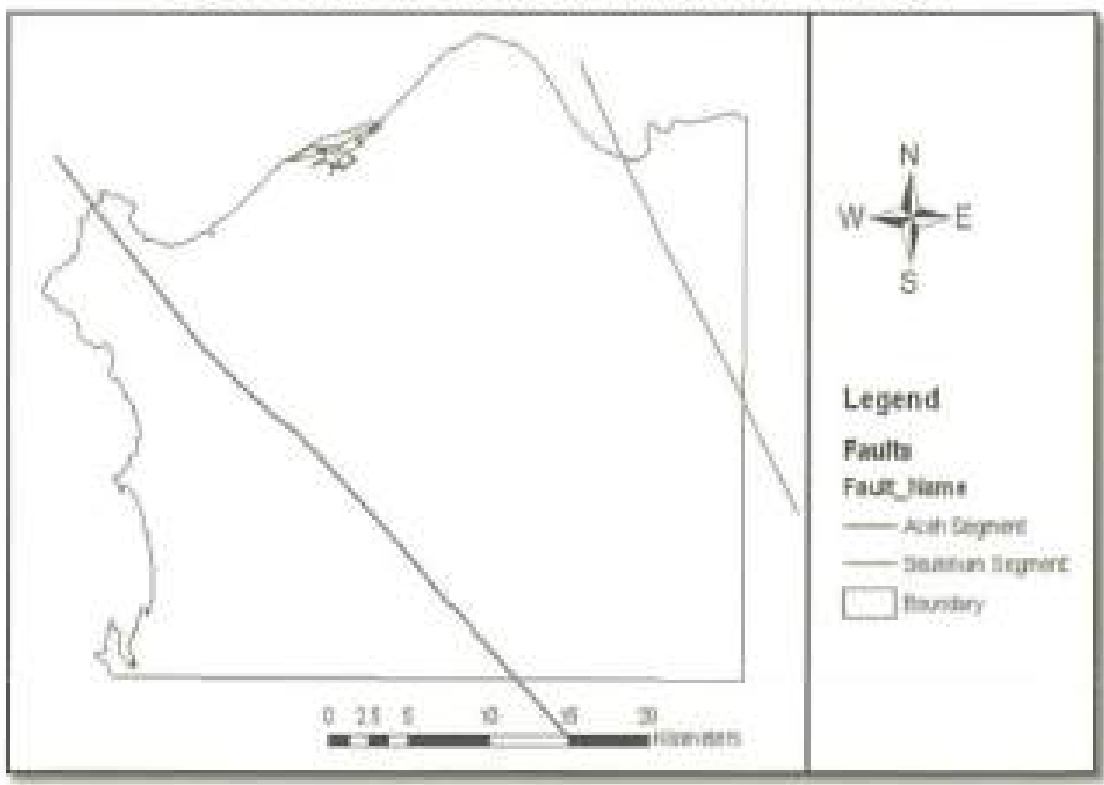

Figure 9: Fault Data Layer 


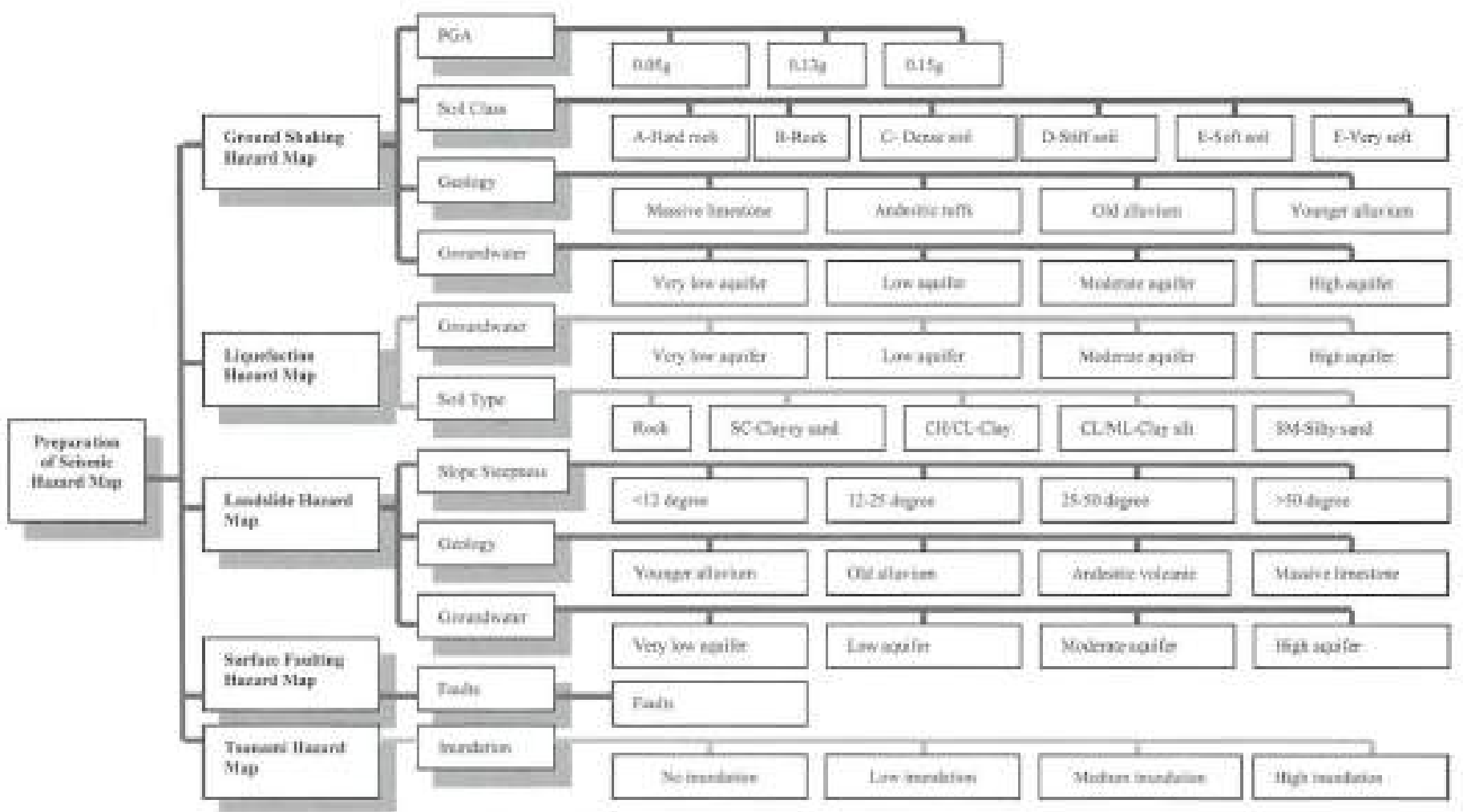

Figure 10: Seismic Hayand and its Parameters 
PLANIVING MALIYSSA

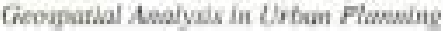

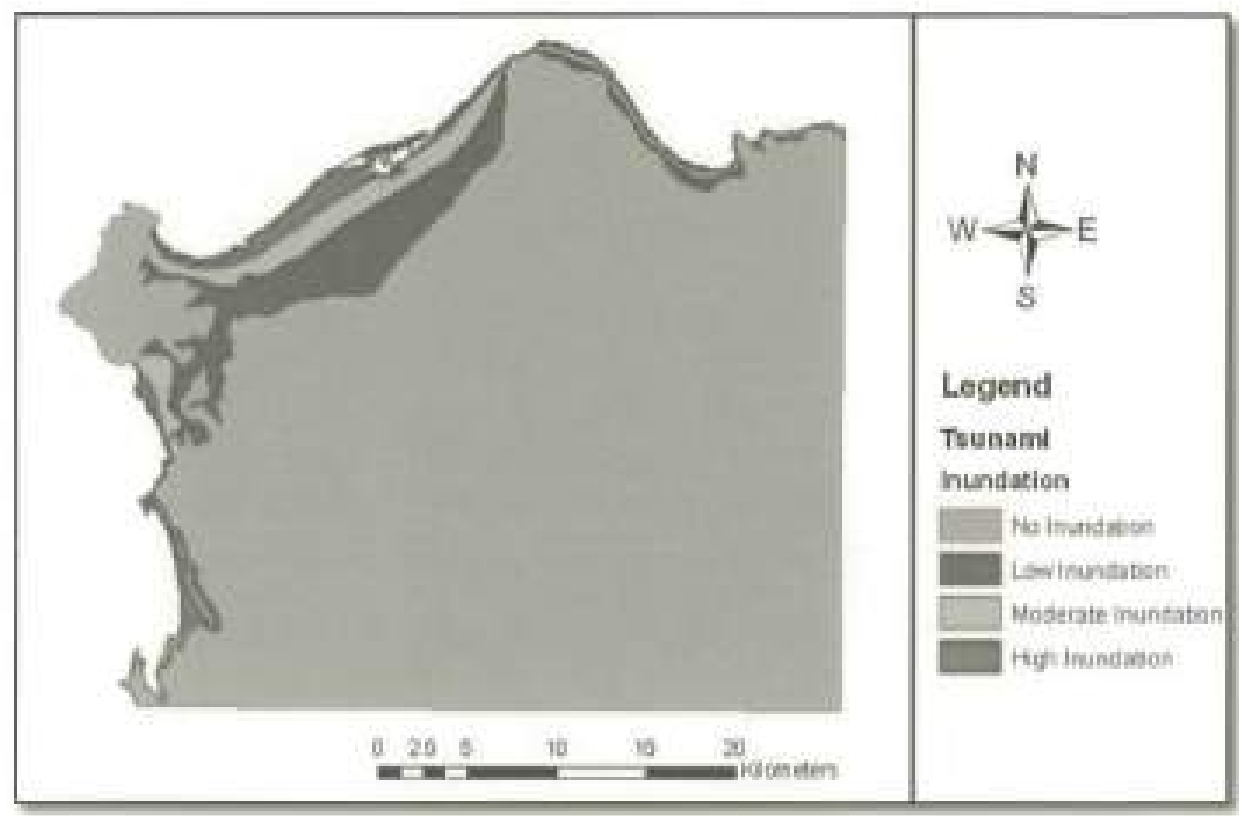

Figure 11: Tsunami Data Layet

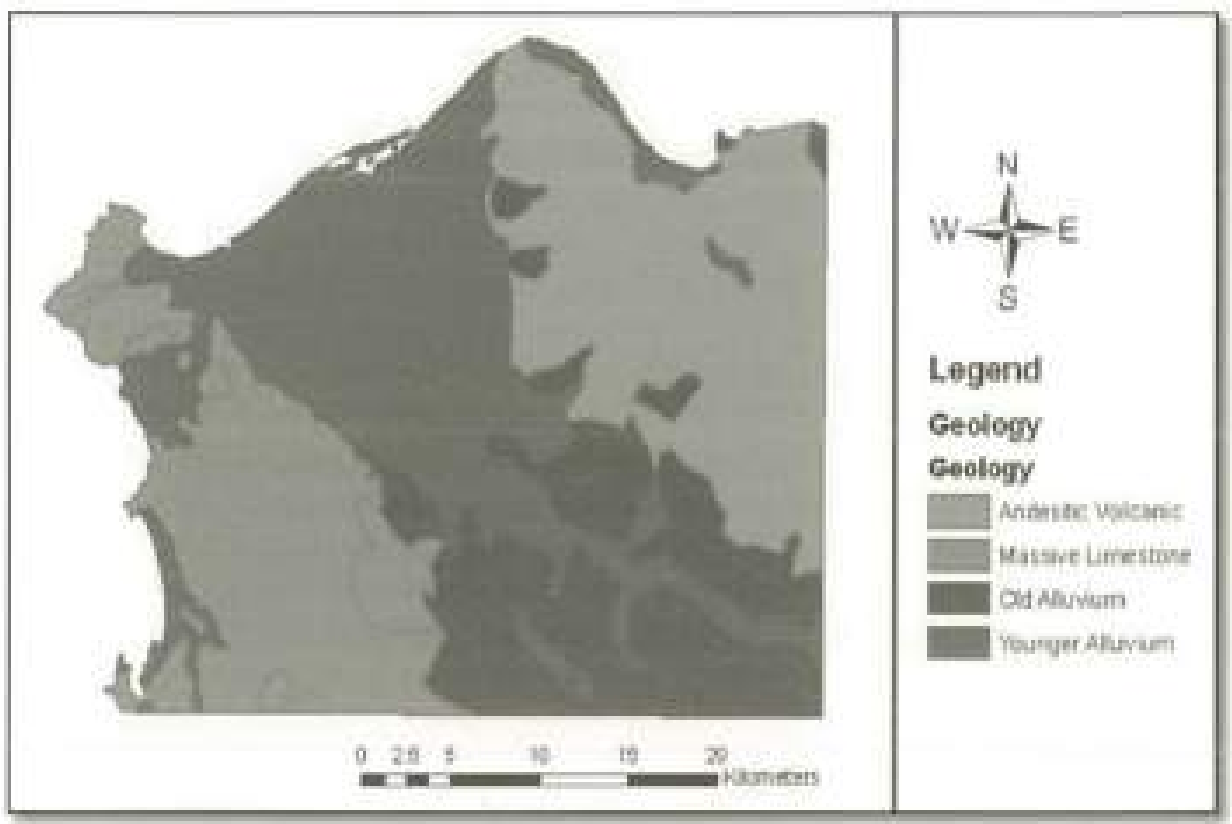

Figure 12: Geology Data Layer 


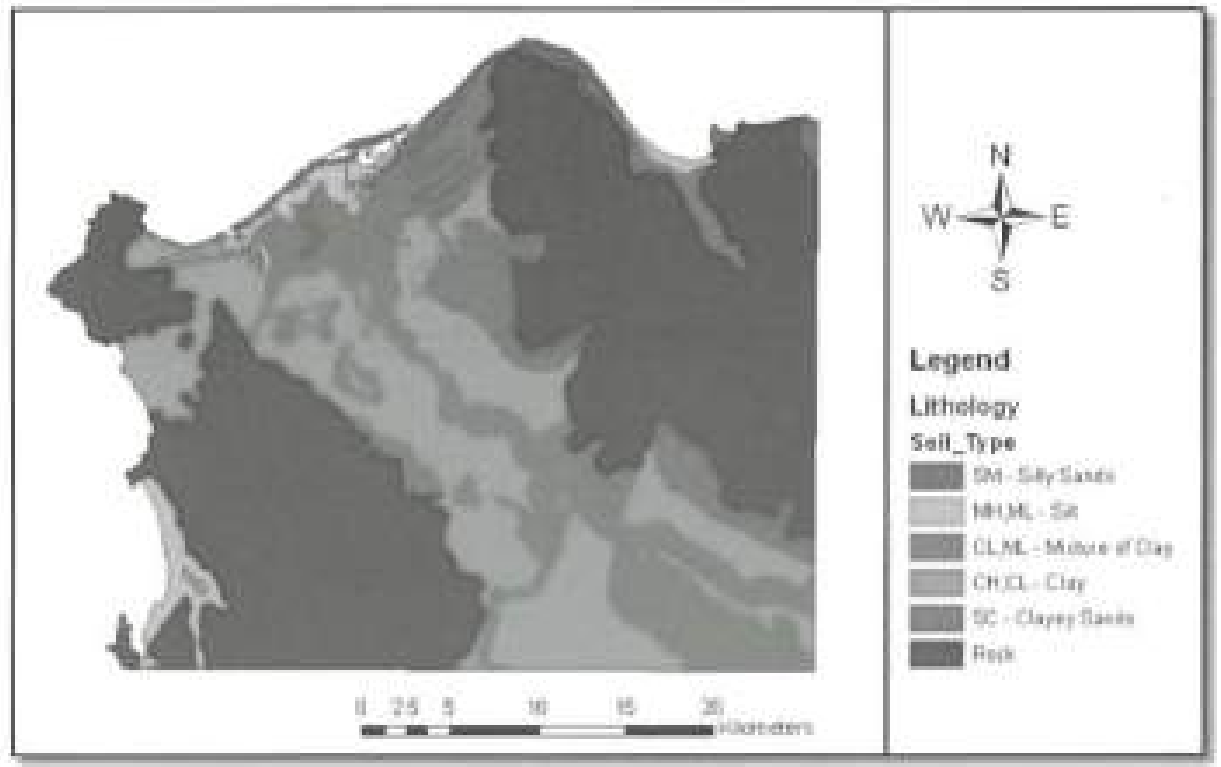

Figure 13: Soil Type Data Layer

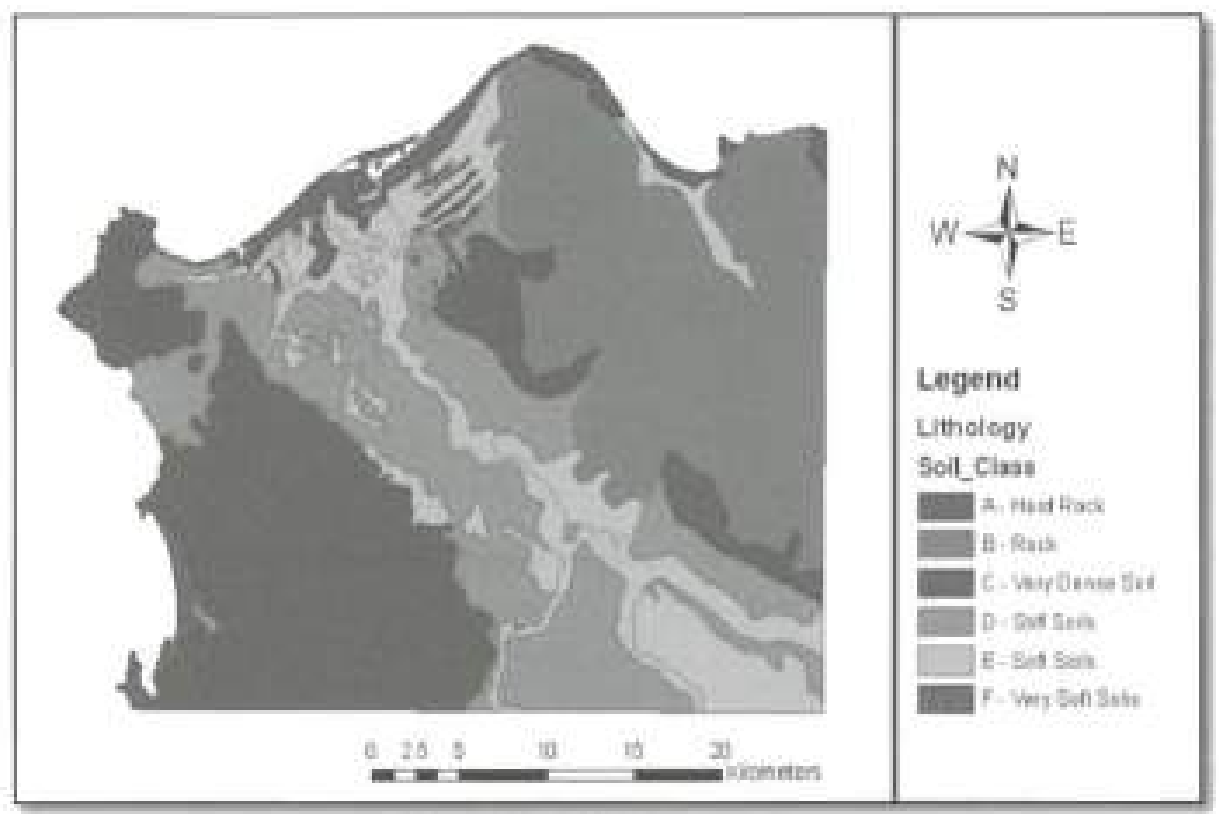

Figure 14: Soil Class Data Layer 


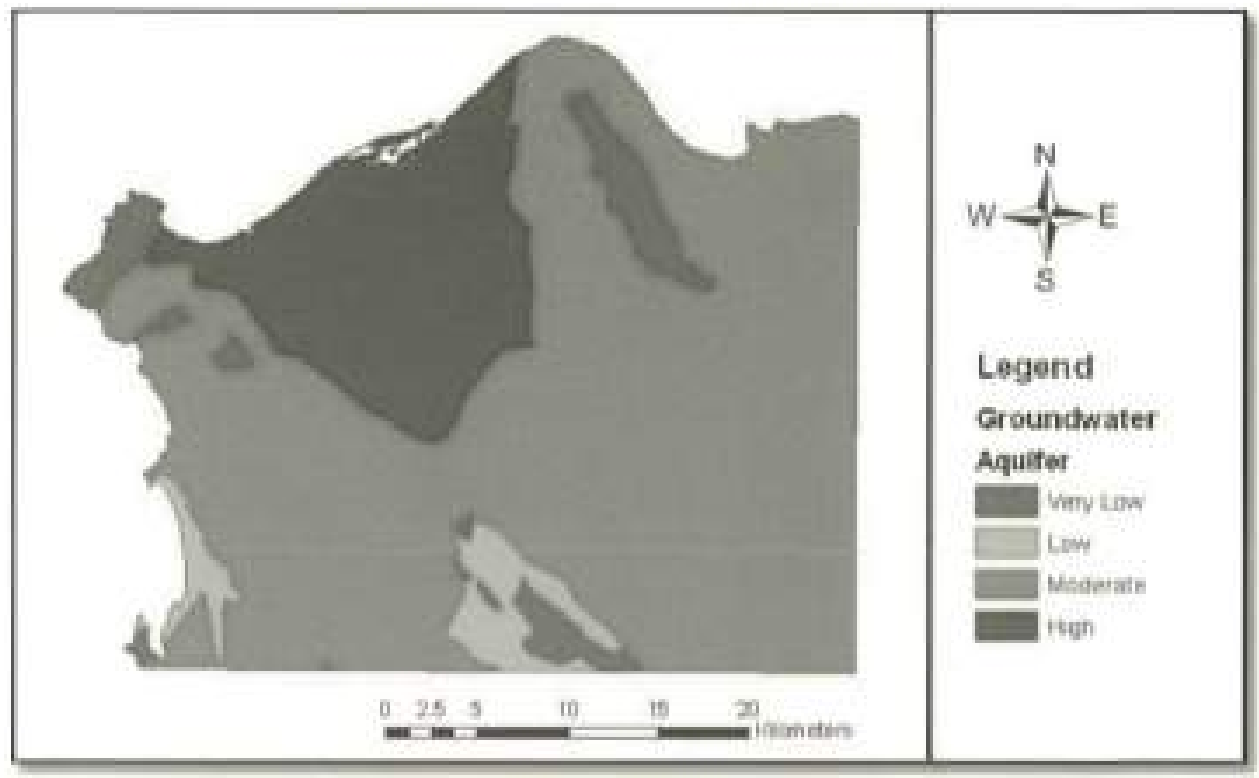

Figure 15: Groundwater data layer

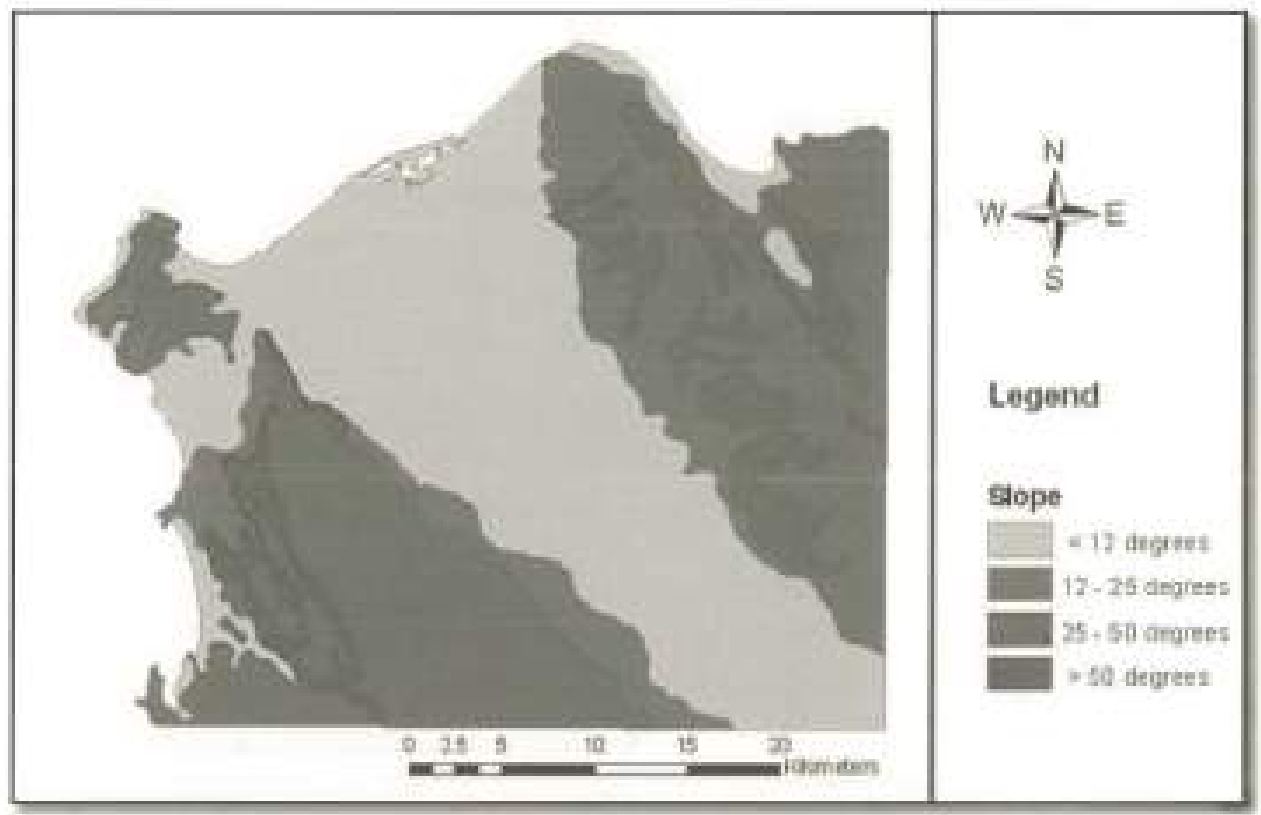

Figure 16: Slope data layer ufter digitized 
Table I: Hazard Areas Generated by Various Hazards Maps

\begin{tabular}{|c|c|c|c|c|c|c|}
\hline & \multicolumn{2}{|c|}{ High Hazand Area. } & \multicolumn{2}{|c|}{ Mediuan Hazard } & \multicolumn{2}{|c|}{ Low Hacand } \\
\hline & Hoxtares: & $\%$ & Hectares & $\%$ & Hectares & $\%$ \\
\hline Ground shaking map & $6,055,58$ & 5 & $30,455.52$ & 25,76 & $81,737,47$ & 60.12 \\
\hline Liquefaction map. & 2.451 .82 & 2 & $8,567.05$ & 7.25 & 81.737 .47 & 90.68 \\
\hline L.andslide hazard mup & $4,142.73$ & 35 & $24,644.01 \mathrm{I}$ & 20.84 & $89,461,83$ & 75.66 \\
\hline Surface faslling & $20,710,09$ & 17.5 & + & + & 97.538 .48 & 82.50 \\
\hline Tsamami inuadation & $6,534.69$ & 5.53 & $8,0012.41$ & 6,77 & $103,711,47$ & 87.71 \\
\hline
\end{tabular}

Table 1 shows the fotal areas in term of hazard level generated by various thematic maps. In general, relatively large proportion of areas, i.e. approximately $70 \%$ and more are classfifed as low hazard zone. The area around the city centre, which is located on recent alluvial plain and amounts to about $5 \%$ of the whole area, has been identified as a high hizard zone and will be most affected by ground shaking. While the valley along the river, which is on predominantly old alluvial plain is categorised as medium hazard zone and the hilly and mountain urea, suggesting $u$ dense soil or rock, is eategorised as a low hazard zone. The liquefaction map on the other hand shows only $2 \%$ high hazard zone, which is the beach area that is located on silty sand with high groundwater depth; while the areas located on silt, mixture of silt and clay with high groundwater depth are eategorised as medium hazard zone, and areas located on clay, elayey sand and rock as low bazard zone. The high hazard zone in terms of landslides effect is an area that lies on massive limestone with slope $>50$ degrees; while the medium hazard zone is also located on massive limestone and andesitic tuffs but with slope of between 25-50 degrees, and the low hazard zone is located on an older and recent alluvial plain. The surface faulting susceptibility map is created by buffering and elassifying the area into two hazard zones categories); low hazard (areas $>2000$ meters from faults), and high hazard (areas $<2000$ meters around the faults). The map shows $17.5 \%$ of the area as high hazard and the other $82.5 \%$ as low hazard. The tsunami hazard map is developed based on the tsunami that occurred on $26^{\circ}$ December 2004. The tsunami hazard map was classified into three zones: low, medium, and high hazand zones. The resulting map shows $5.53 \%$ of the area as high hazard zone or areas having tsunami inundation of more than 3 meters thus experiencing total building damage, $6.77 \%$ as medium hazard zone or areas inundated in 0 2 meters and having slight buildings damage while the remaining area is identified as low hazard area. The high hazard zone is located within $0-2.5$ $\mathrm{km}$ inland from the coastline; while medium hazard zone is located within I - 5 $\mathrm{km}$. 


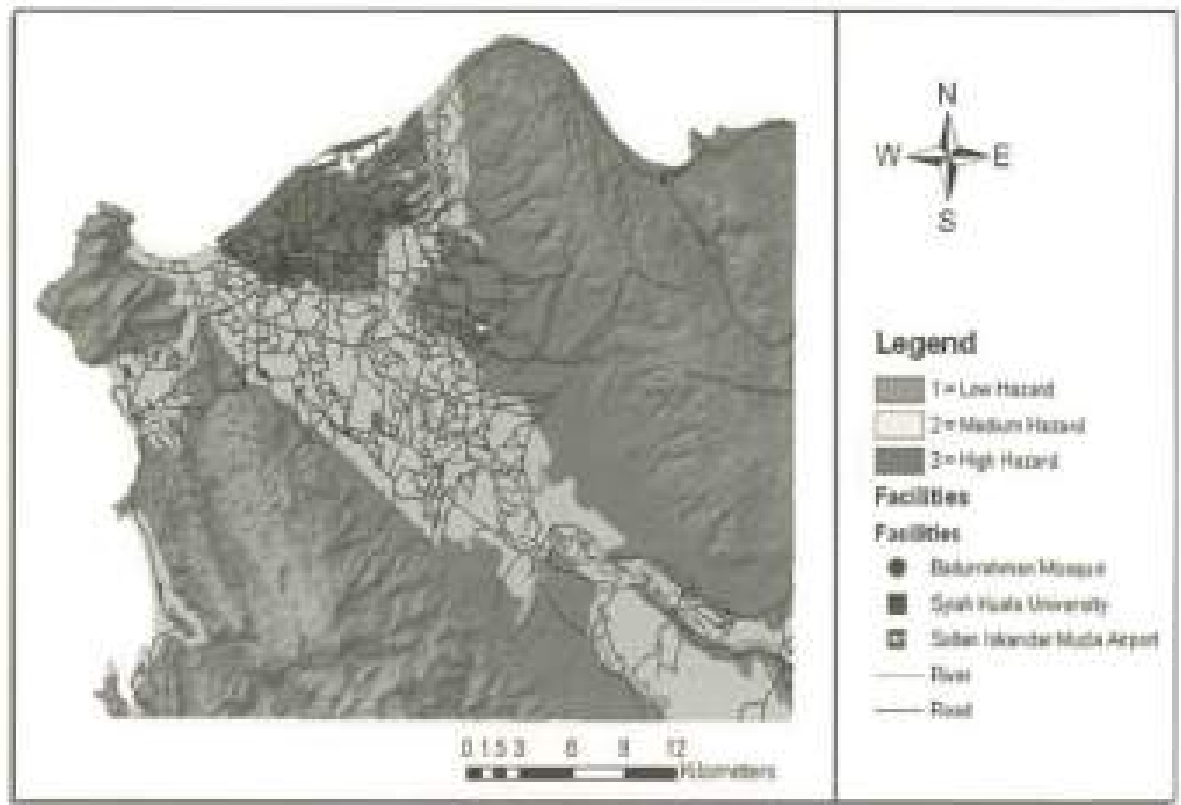

Figure 17: Ground Staking Hazard Map

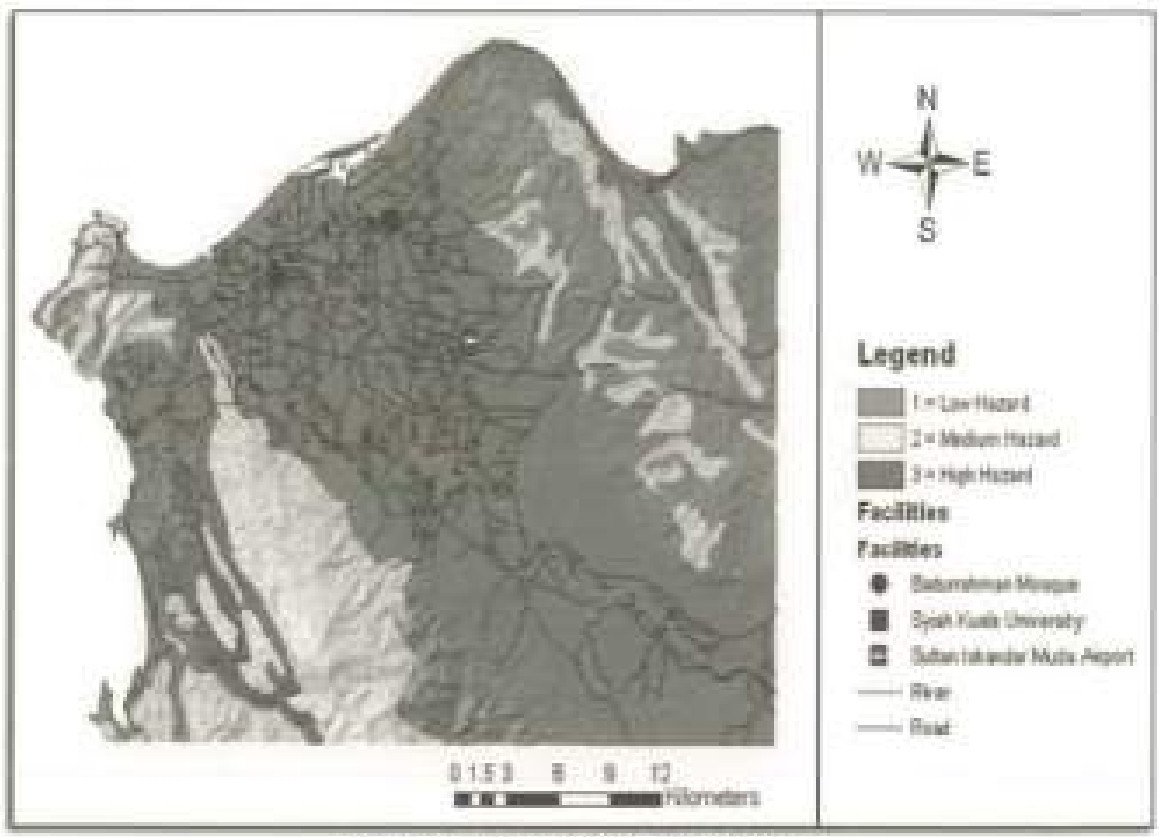

Figure 18: Landslide Hazand Map 


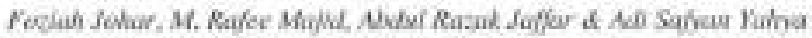

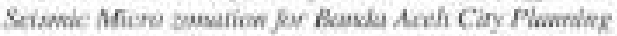

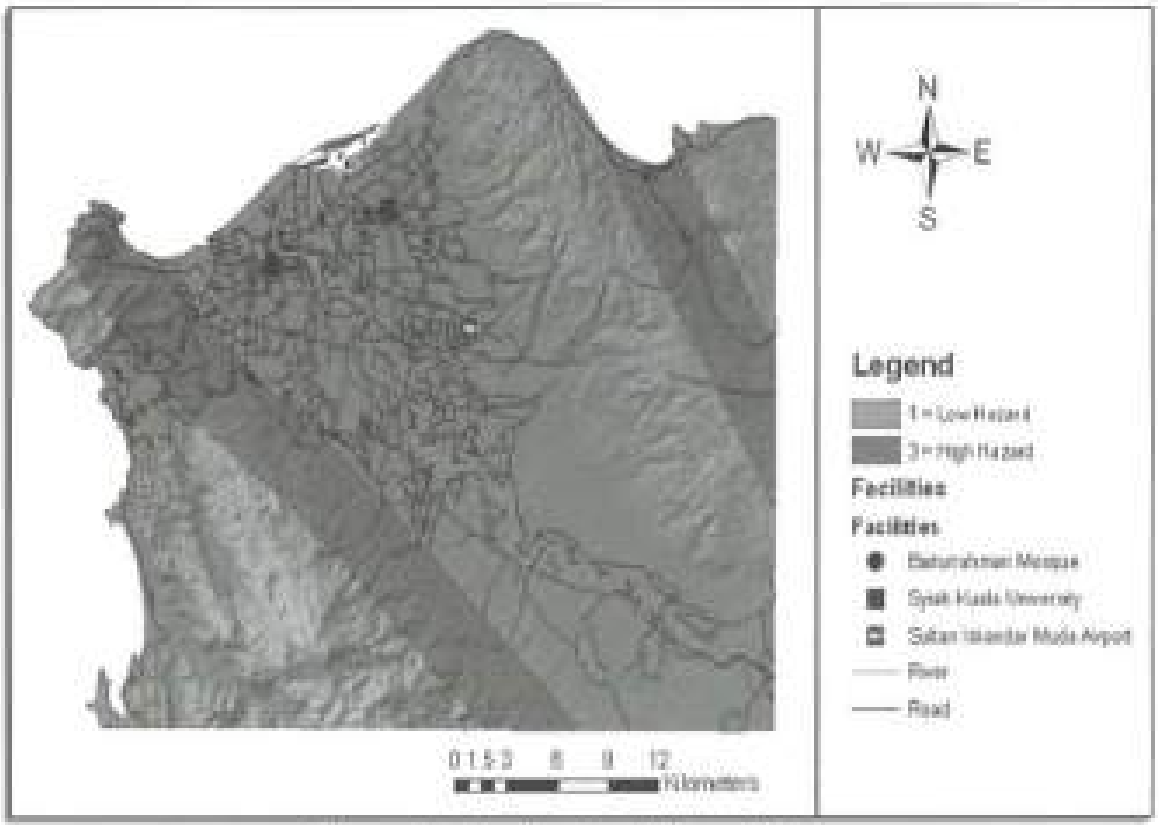

Figure 19: Surface Fault Hazard Map

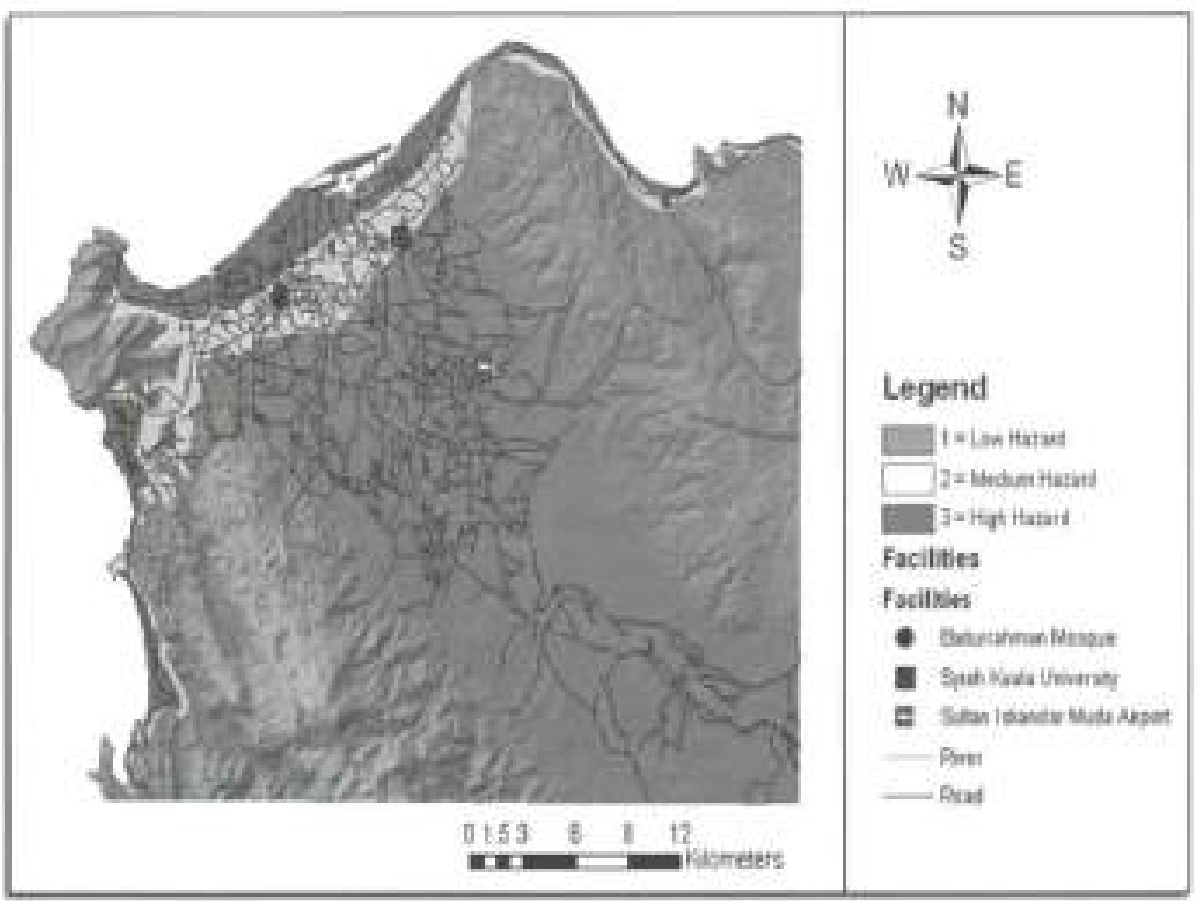

Figure 20: Tsunani Hazard Map 
The final seismic microzonation map is the composite of all the thematic maps i.e, ground shaking hazard map (Figure 17), liquefaction hazard map, landslide hazard map (Figure 18), surface faulting hazard map (Figure 19), and tsunami hazard map (Figure 20). The final map (Figure 21) identifies areas with varying hazards levels essential for land use management and city planning in order to mitigate the impact of the earthiquakes. The final map shows $28.67 \%$ or $33,897.00$ hectares of Banda Aceh as high hazand zone, $38.00 \%$ or 44.935 .29 hectares as medium hazard and $33.33 \%$ or $39,416.28$ hectares are identified as low hazard. The knowledge ubout possible disasters and the varying levels of hazards that might be affecting a region is invaluable for urban planners in directing future urban development to relatively safer areas thus avoiding insurmountable damages and castalties.

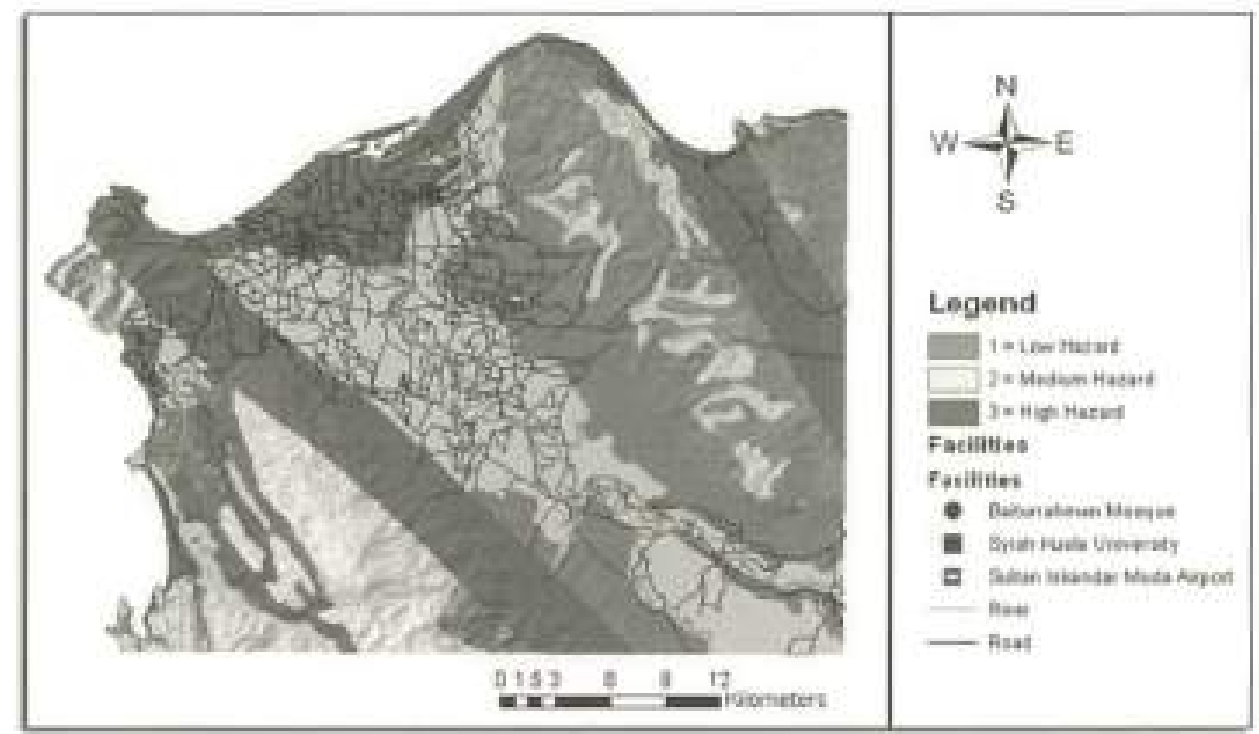

Figure 21: Final map showing different levels of hazard

\section{CONCLUSION}

Recent earthquakes hawe had huge impacts especially to developing countries and most of the blame has been placed on poor planning and construction practices. In disaster susceptible regions the ability to identify and avoid highly hazardous areas is pertinent to minimize casualties and damages, By using GIS, it is possible to produce a seismic microzonation map that analyses seismic risks (hazards) and thus provides assistance to urban planning. In the case study for 
Banda Aceh, a first level seismic microzonation map has been developed based on weighted parameters of seismological, geology and topographical features.

With the microzonation map it is hoped that future development will be able to avoid highly hazardous areas of related hazards and facilitating safer building codes and urban planning practices. It is a tool city planners and policy makers can use to assist in their planning decision or in taking precautionary measures prior to the construction of structures.

\section{REFERENCES}

AFPS French Association for Earthgaake Engineering (1995) Giddelises for seismic Microsmadien Shifies. Paris

Ansal, A., Tonuk, G. and Kurtulus, A. (2019). Microwanation for Uibun Pianning, In Tankut, A.T. (Ed.) Earthyouker and Tsmaworis, 133-152. Londone Springer

Alexander, D.E, (1995), A Sarvey of the Field of Natural Hazards and Disaster Stadies. In: Camin, A., Guzxeti, F. (Eds.), Geographicul hofonmadion Systems in Asvessing Natural Hasem ds, Kluwer Acadenic Pableshers, Dordrecht. 1-19.

Anbachagen, P. and Saharam, 'T. G. (2008). Scismie Microzonation of Bangalore, fodia. Jowrma' of Earti System and Science, $2008(117), 833-852$.

Boen. T. (2005). Swmatra Earhigmale 26 Dec 2004, Earthomake Enginecring Research Institute (EERI).

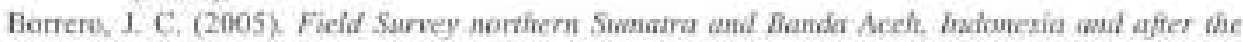
Trmanai and Eanhumale of 26 Decromber 2004, Earthquake Engineering Research Instituste (EERI).

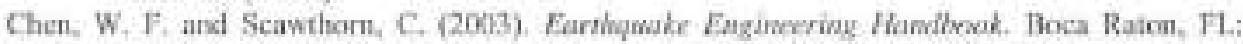
CRC Press.

Btaikic, 1.. Canmon, T. Davis, 1., Wisner, B, (1904) Al Risk, Nowural Hastands, People's Vulnerability, and Disatiers, London, Routledge.

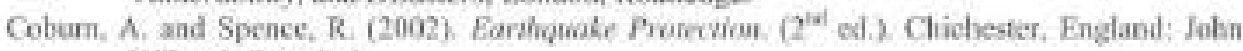
Wilky \& Sons Ltd.

Culshaw, M. G., Duncan, S. V, and Sutiris, N. R. (1979), Engincering Geological Mapping of The Banda Aoch Aluvial Besin, Northern Sumsiera, Indonesia, Bulletin of the Insermationut Assobicition of Engineering Goofogy, 19, 40-47.

Doloe, M. (2009). Mitigation of Seismic Risk in Italy Followisg the 2002 S. Gitulano Earthquake. In Tankut, A.T. (Ed.) Eurwherahes ind 7sunamis, London; Springer, 66-89.

DRM/GDDA World Institute fox Disaster Risk Management, Inc. and General Directorate of Disaster Aflairs, (2004). Seismic Micrononation Mutual For Municipalities.

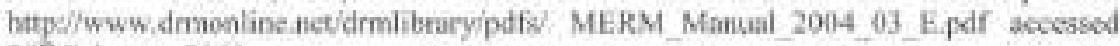
$20^{\mathrm{m}}$ February 2012

Gresse, S, Maugeri, M. (2009). The Secsmic Microzonation of the City of Catania (Italy) for the Maximum Expected Scenario Earthquake of January 11, 1693. Sovif Drwamics and Earthquake Enginecrimg, 29,953-962.

IDNDR (Intermational Decade for Natural Disaster Reduction). (1990) Cíies at risk: Moking Cines Sufier - Before Disaster Swikes. Genew. IDNDR.

Hough, S.E. and Bitham, R. (2005). Afier the Earth Quakes: Elastic Rebuwnd on an Urban Planet, Oxford Universicy Press, USA. 
Kienzle, A. Hannich, D., Wirth, W, Ehret, D., Rohn, J. Ciugudean, V. Cxurda, K. (2000). A GIS-bused Study of Earihquake Hazard as a Tool for the Micromonation of Bucharest. Engineering Gevology, $87(1-2), 13-32$.

Kolat, C., Doyuran, V. Ayday, C, and Sibzen, M. L, (2006), Preparation of a Geotechnical Microzonation Model Using Goographical Information Systems Based on Multicriteria Decision Analysis. Engineering Genologe, 2006 (87), 241-255

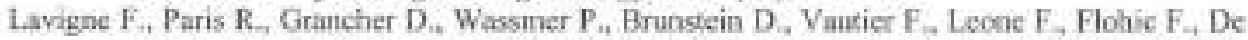
Casier B. Gunawan T., Gomez C., Setiawan A., Cahyadi R., Fachrizal, (2009). Reconstnietion of Tsumami Inland Propagation on December 26, 2004 in Banda Aceh. Indonesia, through Field Investigntions, Pure and Applicd Geophysics, 166, 259-28I.

Malczewski, J. (1999). GIS and Mulbicriteria Decision Amabsis. New York: John Willey and Sons Ine.

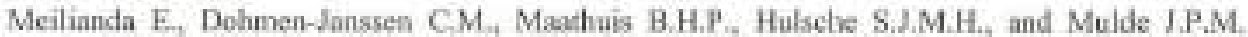
(2010). Short-term mophological responses and developmeats of Banda Aceh coast. Samatra Island, Indonesia afler the Isuarmi on 26 December 2004. Marine Geslogy. $275,(1-4), 96-109$.

Mitchell, I. (ca.) (1999) Crunifles of Hazands: Mega-tities and Disaters in Transitim, Tokyo. United Nations University Press.

Mohanty, W. K., Walling, M, Y. Nath, S. K, and Pal, L. (2007) First Order Seismic Microzonation of Delhi, India L'sing Geographic Information System (GIS). Natural Masarilk, 40, 245-260.

Papadimitriou, A.G., Antoniou, A.A., Boockovalas, G.D., Marinos, P.G., (2008). Methodology for untomated GIS-aided scismic mierovonation studies. Compunters and Gerotechnics, $35(4), 505-523$.

Pelling, M. (2003) The Vwinervatilisy ef Citses, Loedon, Earthscati.

Nath, S. K., Singh, K. K. and Raj. A. (2008), Earthquake Hazand in Northeast Inda - A Seismic Microzonation Approach with Typical Case Studies from Sikkim Himalaya and Guwahati Ciry. Jasmal of Eernh System and Science, 117, 809-831.

Nath, S. K. (2005). An Initial Model of Setsmic Microzonation of Sikkim Himalaya through Thematic Mapping and GIS Inteyration of Geological and Strong Motion Features. Journd of Axim Earm Sciences, 2005 (25), 320-343.

Nath, S. K. (2004). Seiamic Hazard Mapping and Microzonation in the Sikkim Himalaya through GIS Integration of Site Effects and Strong Ground Mocion Attributes. Nawnal Hosards, 31. 319-342.

Panza, G.F, Roumalli, F. \& Vacari, F- [2001]. Seismic Wave Propaeation in Laterally Hetcrogencous and Elastic Media: Theory and Application to seiszusc zonation. Adyunces in Geoplysics, 43, 1-95.

Organization of American States, DRDE. (1991). Priener on Notural Hasond Manazewient is

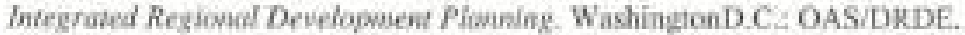

Petersen MD., Dewey J., Hartzell S., Maeller C., Stephan Harmsen S., Frankel A.D., Rukstales K. (2004), Probabilistic Seismic Haczand Analysis for Sumatra, Indonesia and Across the Southern Malaysian Pexingala. Tecronophysics, 390, 141-158.

Roca, A. Goula, X., Susagna, T. Chávez, J, González, M. and Reinoso, E. (2006). A simplified Metbod for Vulnerability Assessment of Dwelling Buildings and Estimation of Dumage Scenarios in Spaie. Bulletin of Earshgwake Enjinecring 4:2,141-158.

Saaty. T. L. (20018). Decision Making with The Analytic Hierarchy Process. Internatianal Jonernal Services Sciences, ifly

Sengara, I. W. Latice, H. asd Kusuma, S. B. (2008). Probabilistic Seismic and Tsunami Hazand Analysis foe Design Criteria and Disaster Mitigation in Rehabilitation and Recanstruction of a Coastal Area City of Banda Aceh. In t Lib, Deng and Chu (Eds.). 


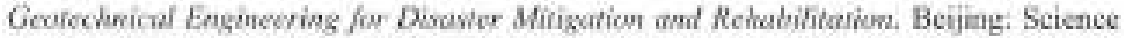
Press and Springer - Verlag GimbH, 224-230.

Sich, K., and Natawidjaja, D. (2000). Neotectionics of the Sumatran Fault, Indonesia. Joursof of Gerublyiad Resounch, 105, 295-326.

San, C, G. et.aL. (20ios) Develogoment and Application of a GIS-bosed Tool for Earthquake-

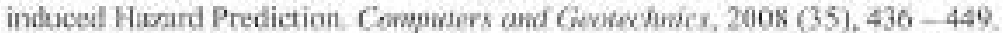

Sun, J, and Pan, T. C. (1995), The Probability of Very Large Earthquakes in Sumatra. Builetin of the Seivondogienal Society of Anacrica, 85(4), 1226-1231.

Sanderson, D. (2000) "Cities, Disasters and Liweliboods", Emvinomment and birowisation, 12(2). 93-102.

Takahasi, M. et,al, (2007), Restoration after the Sumatra Earthquake Tsanami in Barda Aceh : Based on the Results of Interdisciplinary Reseurctes by NogoyaUniversity Soivmal of Nowiral Distsier. Sejence, $29(2), 53-61$.

TC4-ISSMGiE, (1909). Mantwal for Zonation on Seismair Geutecannical Hazard. Revised Edition. Technical Committec for Earthquake Geotechnical Eagineering (TC4) of the International Socicty of Soil Meehanics and Geotochaical Engineeting (ISSMGE) 200.

Turk, T., Gumesay, U., and Tutar, O. (2011). Creating infrastructure for seismic microznaativa by Geographical Infonmation System (GiS): A case stody in the North Amatolian Fatit Zone (NAFZ), Computers \& Geoscience. Doi.10.1016ij.cageo.2011.10.006

Emitsa, M., Tunavud, C. and Patanakasog, B. (2097). Effeets of landfonns on Tsansani Flow in the Plains of Banda Aceh, frdooesia, and Nam Khen, Thailand, Journat of Marine Geofogy, Geochemistry anul Geopleysies, 03595, I-13.

UNDP-BCPR. (2004), Reducing Diruster Risk: A Challenge for Develogunent, New York, John S.

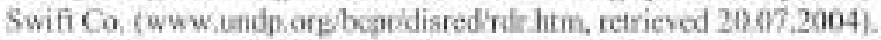

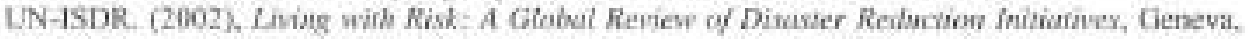
United Nations Inter-Agency Secretarint.

Velasçuez, G., Uitto J., Wisticr B., Takalsashi-S. (1999). A New Approuca to Disaster Mitigation and Planning in Mega-cities", In: Inoguithi, T. (ed.) Cities and the Envrynmes. Tokyo. The United Nations University Press. 161-184.

Walline M. Y. and Mohasty, W. K. $\{2000)$. An Onorvicw on The Seismic Zonation and Micrononation Stadies int Indiz. Earzih-Sriemire Reviewr, 96, 67-91.

Wamsler C. \{2004). Manasing Urban Kisk: Perceptions of Housing and Planning as a Tool for Rodweing Disaster Risk. Gohnd Birih Envmmmene Review. 4(2), 11-28.

Westen, C. I. (2002). Remote Sensang and Goggraphic Information Sysiems for Natural Disaster Marugement. In Skidmore, A. (Ed). Envirownowal Modelling with GS and Remate Sensing: London: Taylor \& francis, 200-226.

Worfd Institute for Disaster Risk Management, luc, and General Directorate of Desaster Affains

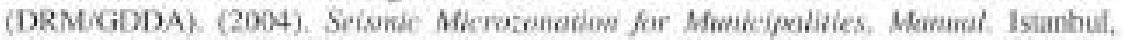
Turkey: DRM/GDDA Ministry of Public Works and Senternent.

Yilmaz, 1., (2009). Landslide Susceptibility Mapping Using Prequency Ratio, Legístic Regression, Artificial Neural Networks and Their Comparison: a Case Study from Kat Landslides (Tokat-Turkey). Compuierz \& Geaseiences, 35, 1125-1138,

Tachriasen, J. Sich, K., Taylor, F, W, Edwards, R. L., und Hantore, W, S. (1999), Subunergence and Uplift Associated with the Giant 1833 Sumatran Subdaction Earthquake. Evidence

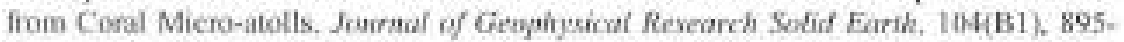
919. 